\title{
携帯式蛍光光度計を用いた付着藻類の 現存量測定による造成干潟の環境調査
}

\section{FIELD EXPERIMENT OF CHLOROPHYLL-a IN SITU QUANTIFICATION FOR BENTHIC ALGAE USING PORTABLE FLUOROMETER}

\author{
高尾敏幸 1 ・北野倫生 ${ }^{2}$ ・ 山本秀一 3 ・ 小田秀夫 ${ }^{4}$ ・岡田知也 5 \\ Toshiyuki TAKAO, Michio KITANO, Hidekazu YAMAMOTO \\ Hideo ODA and Tomonari OKADA
}

\author{
1正会員 工修 株式会社 エコー 沿岸デザイン本部（テ110-0014 東京都台東区北上野2-6-4） \\ 2正会員 博(工） 株式会社 エコー 沿岸デザイン本部 \\ 3 正会員 博(生物資源工学) 株式会社 エコー 沿岸デザイン本部 \\ 4理博 日本海洋株式会社 環境調査・機器事業部（广114-0005 東京都北区栄町9-2） \\ 5 正会員 工博 国土技術政策総合研究所 沿岸海洋研究部（广239-0826 神奈川県横須賀市長瀬3-1-1）
}

\begin{abstract}
Field experiments to estimate chlorophyll $a$ of benthic algae habited at tidal flat were carried out by using portable fluorometer in the period from February to September, 2005. Chlorophyll $a$ values obtained by fluorometer with in vivo analysis and by chemical analysis of DMF reagent indicate approximately in linear. The fluorometer method was introduced to measure a distribution of benthic algae quantity in some different conditions. For example, the survey results indicated that quantity of benthic algae was related to the habited ground elevation. It is ensured by the field test that this portable fluorometer enables much easily to evaluate a distribution of benthic algae.
\end{abstract}

Key Words : Chlorophyll a, Benthic algae, Tidal flat, Field Experiment, Ecosystem

\section{1. はじめに}

干潟は生物による生産性が高く，魚介類の産卵の場や 幼稚仔魚の生育場となっているだけではなく, 多様な生 態系が構成されていることから水質浄化機能なども有し, 沿岸河口域における物質循環の重要な場となっている1). この中でも特に光量に恵まれた底面上に生育する微細な 付着藻類の生産量が様々な機能の基礎となっているもの と考えられる. したがって, 干潟の基礎生産者の現存量 を調查することは干潟の各種機能のポテンシャルを評価 する上できわめて重要である.

これまで, 干潟の基礎生産者の現存量は, 試料採取と 分析により行われており，代表することのできる点とし ての值で評価してきたのが現状であった.

各地で沿岸域の環境再生として干潟造成が行われてい
る中, 干潟造成後のモニタリング調査がその評価に重要 な位置を占めている.干潟造成後の初期段階においては， 干潟地形は安定する方向へ変化するため2), 従来型の点 としての評価で，面的な代表性を捉えることに難点が あった.

これらに対応するには, 現場でより多くの点で現存量 を測定することが求められる. 本研究では, 短時間で広 域かつ詳細な計測が可能な携帯式蛍光光度計を用い，付 着藻類の現存量の分布形態を定量的に調査する手法につ いて現地調查に基づいた検討を行った。

対象とした干潟は, 図-1に示す東京湾の葛西海浜公園 と船橋海浜公園および大阪湾の阪南2区における造成干 潟である. 葛西海浜公園は，荒川河口部と江戸川河口部 に挟まれた場所に位置し，1989年に開園した人工干潟で ある. 船橋海浜公園は，三番瀬干潟奥部に位置し，春か ら初夏にかけて潮干狩りで有名な干潟である。阪南2区 
における造成干潟は，大阪湾東部に位置し，2004年に造 成された干潟である。この造成干潟では，干潟地形の安 定化および生物定着の促進を目的として，各種の実験区 が設けられ，干潟地形のモニタリングをはじめとする各 種調査が行われている゙).

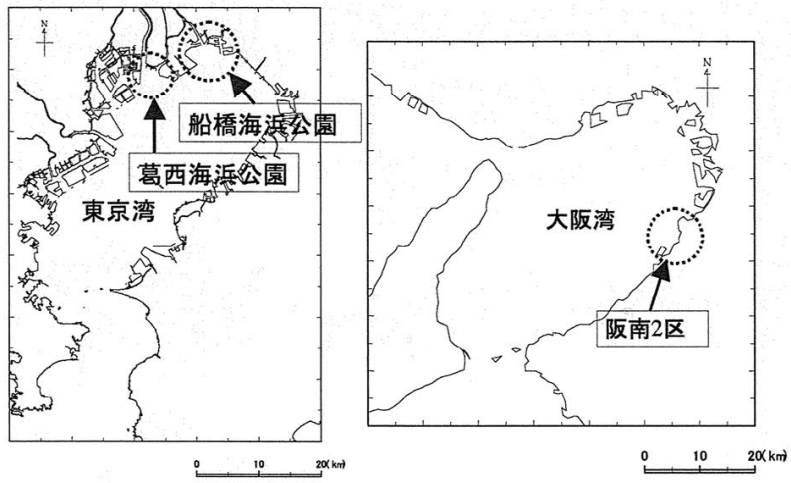

図-1 調查地点図

\section{2. 現地観測}

\section{(1) 測定機器}

本調査で用いた蛍光光度計は，パルス変調 $(5 \mathrm{kHz})$ を用 いたクロロフィル励起蛍光測定法に基づく多波長励起蛍 光光度計(Bentho-Fluor; ドイツBbe社製)である．対象を そのまま非破壊的に測定できること，海水中のプランク トンの光合成活性をそのまま測定できることなど，野外 での測定に適している長所がある。測定は，光化学系 (PS II )アンテナ色素に対して，5波長LED（450nm， $3 \mu \mathrm{Em}^{-2} \mathrm{~s}^{-1} ; 525 \mathrm{~nm}, 7 \mu \mathrm{Em}^{-2} \mathrm{~s}^{-1} ; 570 \mathrm{~nm}, 3 \mu \mathrm{Em}^{-2} \mathrm{~s}^{-1} ; 590 \mathrm{~nm}$, $6 \mu \mathrm{Em}^{-2} \mathrm{~s}^{-1} ; 610 \mathrm{~nm}, 3 \mu \mathrm{Em}^{-2} \mathrm{~s}^{-1}$ ) の励起光源によるターゲッ 卜藻類のアンテナ色素タイプからの蛍光強度 $(685 \mathrm{~nm})$ に より，藻類群集を分別・定量を可能とするシステムであ $ろ^{4)}$.

測定方法は，写真-1に示す光ファイバー（コード）と 先端アダプターにより, 干潟などの表面に存在する藻類 群集に5波長の励起光を $1.5 \mathrm{~cm}^{2}$ の照射面に当て，放出さ れる蛍光強度によって，藻類群集を分別・定量するもの である。测定限界は，クロロフィル-aに対して $0.01 \mu \mathrm{g} / \mathrm{cm}^{2}$, また, 分別・定量（珪藻類, 緑藻類, 藍 藻) が可能な測定範囲は， $0.1 \sim 3.0 \mu \mathrm{g} / \mathrm{cm}^{2}$ である.

この測定方法の特徽として, $1.5 \mathrm{~cm}^{2}$ の基質表面を日中 の1日あたり200検体程度測定することが可能であり，短 時間に多くの測定データを取得することが可能である (写真-2).
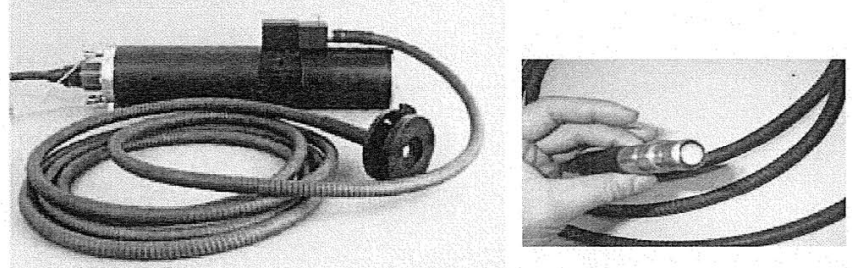

写真-1 測定機器

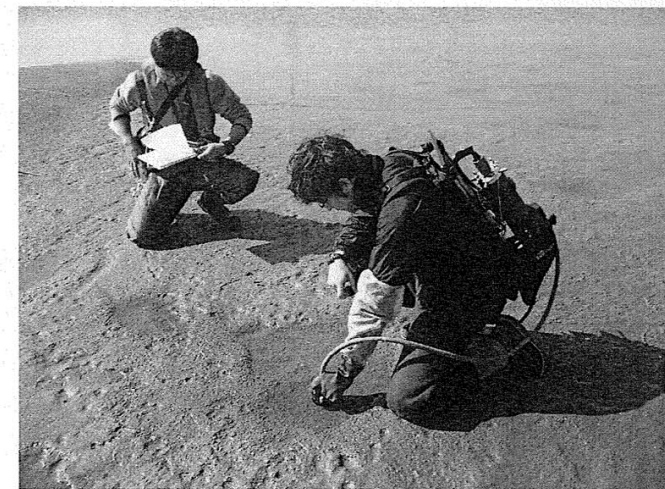

写真-2 測定状況

\section{(2) 現地観測}

2005年5月に東京湾の葛西海浜公園西なぎさと船橋海 浜公園において，2005年2月，2005年3月，2005年9月の3 季に大阪湾の阪南2区における造成干潟においてそれぞ れ以下に記す干潟の付着藻類に関する現地観測を実施し た.

\section{a）分析值との比較}

東京湾の葛西海浜公園と船橋海浜公園の砂干潟で，従 来のDMF法による基質中のクロロフィル-aの含有量 ( $\mu \mathrm{g} / \mathrm{g}$-dry) と，Bentho-Fluorの励起波長の照射イメージに よって定量されるクロロフイル-a $\left(\mu \mathrm{g} / \mathrm{cm}^{2}\right)$ の関係を比較 することを目的とした観測を実施した.

観測は，Bentho-Fluorの測定およひDMFによる抽出を 現場にて実施し，DMF試料については，24時間冷暗所 にて保存抽出後，比色定量した。 また，Bentho-Fluorの 測定結果とDMF法の分析結果を直接的に比較するため, Bentho-Fluorの測定部分(照射面の $1.5 \mathrm{~cm}^{2}$ )を，3から $4 \mathrm{~mm}$ 厚で採取したものを栓付き試験管に取り，速やかに DMF $(10 \mathrm{ml}$ まは20ml) を添加し, 冷暗所に保存した。 これらの抽出色素は，24時間内に比色法により各波長を 測定し，計算によりクロロフィル-aを算出した.

\section{b）クロロフィルーaの平面分布特性}

クロロフィル-aの平面的な分布特性と, 測定回数と測 定值との収束関係について検討するため，2005年3月に 阪南2区における造成干潟で，目視において表面状況が ほぼ均一である干潟底面に $1 \mathrm{~m}$ 枠のコドラートを冠水し ている地点と干出している地点の2箇所に設置した。コ ドラート内で， $0.2 \mathrm{~m}$ 間隔ごとに 16 点の測定を行った.

\section{c）クロロフィル-aの底質中での分布特性}

深さ方向におけるクロロフイル-aの分布特性を把握す るため，2005年3月に阪南2区における造成干潟の3地点 で直径 $5 \mathrm{~cm}$ の塩ビ管を干潟面に差し込んで干潟泥を柱状 採取した. 各地点で2つの試料を採取し，底泥表面のク

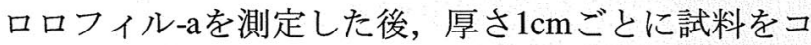
アーから押し出して切断し，深さ5cmまでの6層のクロ ロフイル-aの測定を行った.

\section{d）クロロフィルaの分布と地盤高の関係}

2005年3月に阪南2区における造成干潟で，干潟の岸沖 
方向に間縄を用いて測線を設定し， $4 \mathrm{~m}$ 毎にクロロフィ ル-aとレベル測量による地盤高の測定を行った. 測定は, 間縄を中心とした両側約 $30 \mathrm{~cm}$ の点を含む計 3 点で実施し, 1地点における測定值とした.

\section{e）クロロフィル-aの日変化}

同一日に同じ地点で2回以上の測定を行うことで，干 潟底面のクロロフィル-aの時間変化を調べた。2005年3 月調査では, 2箇所で午後1時から午後1時半と午後4時か ら午後4時半の2回に同一地点で測定した．2005年9月調 查では，2箇所で午前9時から9時半，午前11時半前後， 午後 1 時半前後の 3 回いずれも同一地点で測定を行った. いずれの測定時も干潟は干出条件にあった。

\section{f）クロロフィルーaの季節変化}

2005年2月，3月，9月に阪南2区における造成干潟で実 施した測定值のうち，千潟底面の測定值のみを選び，種 組成について整理を行った。

\section{g) クロロフィルーaの部材別特性}

2005年9月の阪南2区における造成干潟において，干潟 底面だけでなく，竹・杭・転石といった部材ごとのクロ ロフィル-aを計測し，その違いについて調べた。

\section{3. 観測結果}

\section{(1) 分析値との比較}

図-2にBentho-Flourによる測定值 $\left(\mu \mathrm{g} / \mathrm{cm}^{2}\right)$ と従来法の值 (DMF抽出法: $\mu \mathrm{g} / \mathrm{g}$-dry)を示す. Bentho-Flour測定值は, 表面を照射して得られる值であり，一万DMF抽出法は， 厚さ(3〜4mm)の試料中の值である. Bentho-Flour測定值 とDMF抽出法の值の相関係数は, 全地点で $\mathrm{r}=0.812$ とな り，船橋海浜公園で $\mathrm{r}=0.826$ ，葛西人工干潟で $\mathrm{r}=0.995$ を 示し，正の比例関係が得られた。このことから， Bentho-Flourによる非破壊測定法は，砂質干潟の底面上 において，クロロフィル-aの測定に有効であることが推 測された. また, 本測定器による鉛直方向の数 $\mathrm{mm}$ 単位 の精度での観測の可能性を示した.

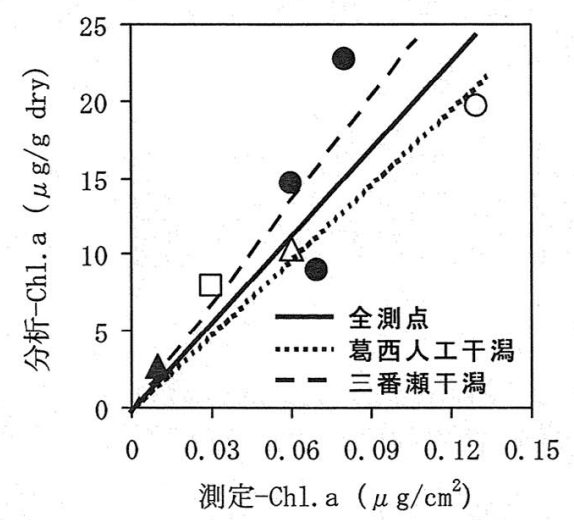

$\bigcirc: 0 \sim 3 \mathrm{~mm} \quad \triangle: 3 \sim 8 \mathrm{~mm} \quad \square: 8 \sim 12 \mathrm{~mm}$ 黒塗：三番瀬干潟 白抜 : 葛西人工干潟

\section{（2）クロロフィル-aの平面分布特性}

干潟底面上に設置した方形枠測定の結果を図-3に示し た。枠 1 は, 平均值 $0.10 \mu \mathrm{g} / \mathrm{cm}^{2}$, 標準偏差 $0.043 \mu \mathrm{g} / \mathrm{cm}^{2}$ で あった。枠 2 は, 平均值 $0.07 \mu \mathrm{g} / \mathrm{cm}^{2}$, 標準偏差 $0.019 \mu \mathrm{g} / \mathrm{cm}^{2}$ であった。このように，目視ではほぼ均一 な底質性状で，測定地点の間隔が $0.2 \mathrm{~m}$ であったにもか かわらず，現存量の分布にばらつきがみられた。 また， 干出していた枠 2 に比へてて冠水していた枠1のばらつきが 大きかったことから，干潟水中では表面のクロロフィ ル-aのばらつきが干出底面に比べて大きいことが推測で きた。

このように分布にばらつきがみられるクロロフィル-a が何回程度の測定で収束するかを調べた。16個の測定值 からランダムに抽出した複数の測定值の平均値を求め, その測定值が16回の測定値の平均值士標準偏差の範囲

(枠 1 では $0.054 \sim 0.140 \mu \mathrm{g} / \mathrm{cm}^{2}$ ，枠 2 では $0.049 \sim$ $0.087 \mu \mathrm{g} / \mathrm{cm}^{2}$ の範囲）に入る回数を抽出し，その割合に ついて調べた結果を図-4に示した. 抽出した測定值の数 を横軸に，16回の測定値の平均值士標準偏差の範囲に 入る割合を縦軸に示す. 測定回数 1 回では枠 1 , 枠 2 とも に，16点の観測值の標準偏差に入る割合は約75\%であっ た. 測定回数3回では, 93〜96\%に, 測定回数5回では, 約100\%が含まれていた.このことから， $1 \mathrm{~m}^{2}$ 範囲内に おいて妥当なデータを得るためには，その範囲内におい てできれば5回，最低でも3点の測定を行い，その平均值 を地点を代表する值とすることが望ましいと考えられる.

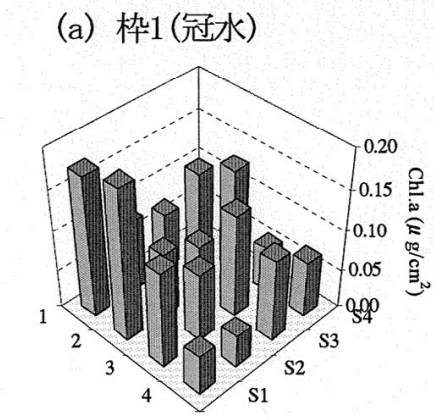

(b) 枠2 (干出)

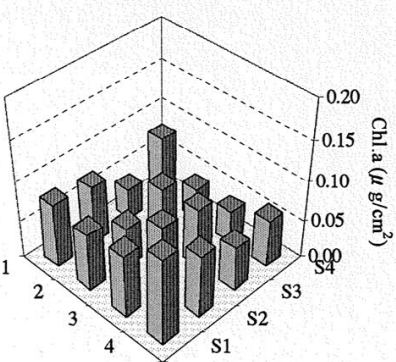

図-3＼cjkstart方形枠測定の結果

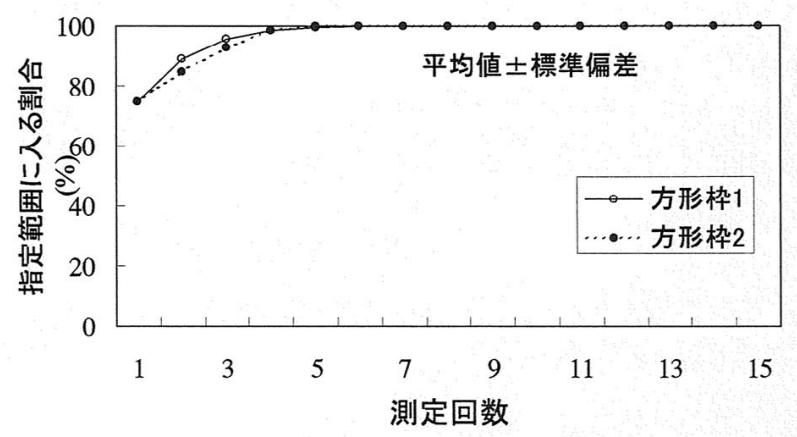

図-4＼cjkstart測定回数毎の平均值士標準偏差に入る割合

図-2ＤMF分析值とベントフローラ測定值の比較結果 


\section{（3）クロロフィル-aの底質中での分布特性}

2005年3月に阪南2区における造成干潟の3地点で採取 した底質コアーサンプルの表層から深さ $5 \mathrm{~cm}$ までの $1 \mathrm{~cm}$ 間隔の測定の結果を図-5に示した。值は，各地点 2 個の 試料の平均值と最大值・最小值を示す。現存量は, Sta.J では深さ $2 \mathrm{~cm}$ で測定されたものの，他の 2 地点では表 層のみで測定された。

また，図-2に示した2005年5月に東京湾の葛西海浜公 園と船橋海浜公園で分析值との比較のために実施した厚 さ3から $4 \mathrm{~mm}$ 間隔の測定の結果を図-6に示した。葛西海 浜公園においては，深さ8mmにおいてもクロロフィル-a が測定された.この結果についても，表層からの鉛直分 布は，表層で最も高い值を示していた。

これらの結果から, 現存量は, 表層で高く, 深くなる につれて減少する分布をしている様子が測定された.こ のことから, 表面の測定のみで面的なクロロフィル-aが 把握できる可能性を示唆した。
(a) Sta. J
(b) Sta. K
(c) Sta. L
Chl. a量 $\left(\mu \mathrm{g} / \mathrm{cm}^{2}\right)$ $\mathrm{Chl}$. a量 $\left(\mu \mathrm{g} / \mathrm{cm}^{2}\right)$ $\mathrm{Chl}$. a量 $\left(\mu \mathrm{g} / \mathrm{cm}^{2}\right)$
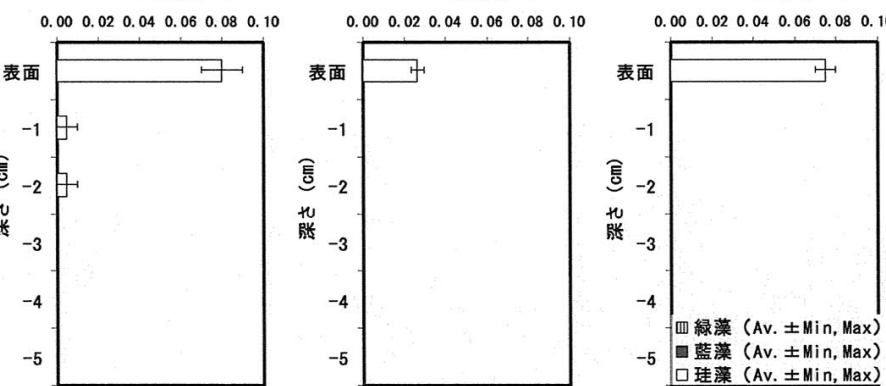

図-5 深さ方向のクロロフィル-aの変化（阪南2区）

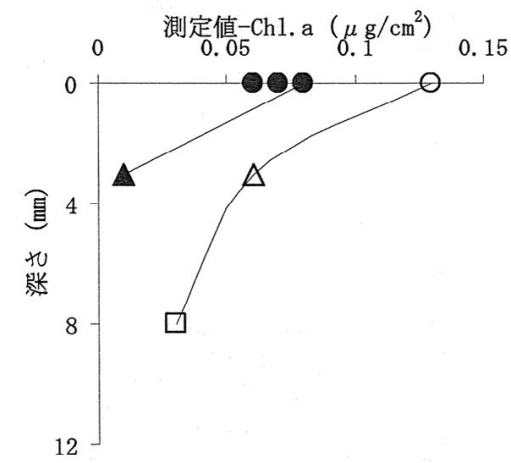

$\bigcirc: 0 \sim 3 \mathrm{~mm} \quad \triangle: 3 \sim 8 \mathrm{~mm} \quad \square: 8 \sim 12 \mathrm{~mm}$ 黒塗 : 三番瀬干潟 白抜 : 葛西人工干潟

図-6＼cjkstart深さ方向のクロロフィル-aの変化 (葛西海浜公園, 船橋海浜公園)

\section{（4）クロロフィル-aの分布と地盤高の関係}

2005年3月に阪南2区における造成干潟で害施した干潟 底面上に設置した測線上のクロロフィル-aの測定結果と 同時に測定した地盤高を図-7に示した。クロロフィル-a
の值は，同一地点の3回の測定の平均值と標準偏差を示 す.また，図-8に2005年2月，3月，9月に阪南2区におけ る造成干潟の観測で得られたクロロフィル-a と地盤高と の関係を示す．測定できる水深は，先端アダプターまで のコードの長さによる制限があるため，D.L.+0.5m以上 の地盤高での測定結果を示す.

D.L. $+105 \mathrm{~cm}$ (M.W.L. $+10 \mathrm{~cm})$ よりも低い地盤高で出現 する傾向にあった(図-8). 図-7の岸沖方向の分布と比べ ると，平均潮位 (D.L.+95cm)よりも低く，海底勾配の小 さい領域で現存量は高い傾向にあった。このことから， 地盤高と海底勾配が現存量を変化させる環境要因になる ことが示唆された。

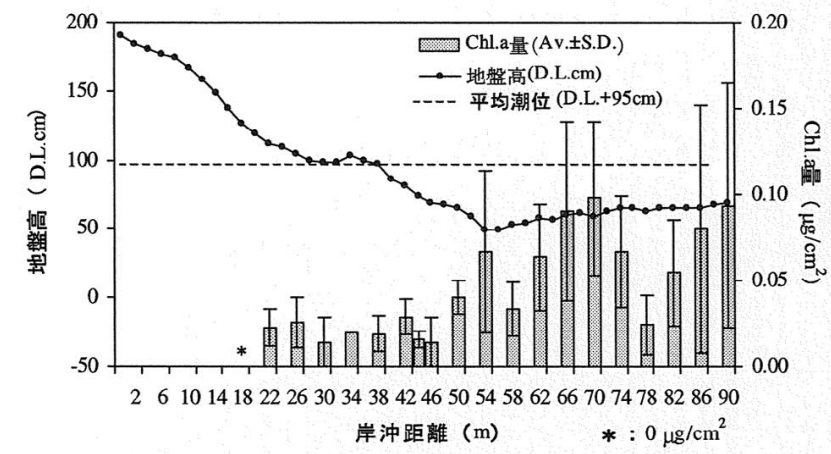

図-7 岸沖方向のクロロフィル-aと地盤高

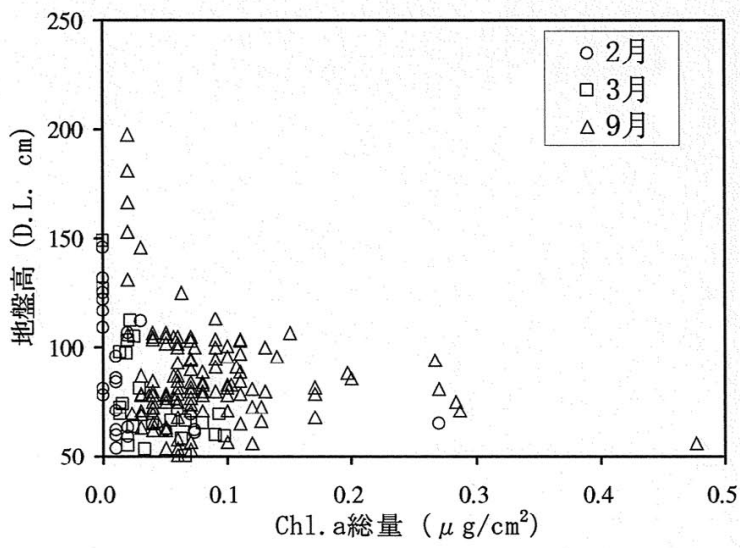

図-8 干潟底面上のクロロフィル-aと地盤高

\section{（5）クロロフィル-aの日変化}

2005年3月と2005年9月に阪南2区における造成干潟で 実施した同一地点でのクロロフィル-a の日変化の2回以 上の測定結果について，3月の結果を図-9に，9月の結果 を図-10に示した. 図のクロロフィル-aは, それぞれ近 接する3点で算出した平均值と標準偏差で示した.

3 月の測定の1回目は，午後1時から1時半の間，2回目 は, 午後4時から4時半の間であった. 地点 2 1 回目と 2 回目の值には大きな差がみられたものの, 地点1は, 1 回 目と2回目は，ほぼ同じ值であった。

9月の測定の1回目は，午前9時から9時半，2回目は， 午前11時半前後, 3回目は, 午後1時半前後であった. 地 
点3は，1回目から2回目にかけて増加し2回目から3回目 にかけて減少しているものの, 明膫な変化を確認するこ とができなかった，地点4についても，1回目から3回目 にかけてわずかに増加しているものの，明膫な変化を確 認することができなかった。

干潟の付着藻類の基礎生産は, 底生生物の餌となる十 分な量があるといわれている5゙。このため, 既往の知見 を踏まえると, 日変動を把握するためには，今回のよう な3回の測定では明瞭な変化を観測することは難しく， 測定回数を留意する必要がある.

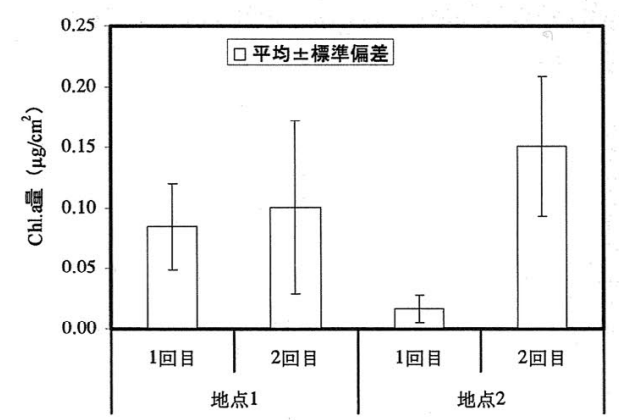

図-9 クロロフィル-aの時間変化(2005年3月)

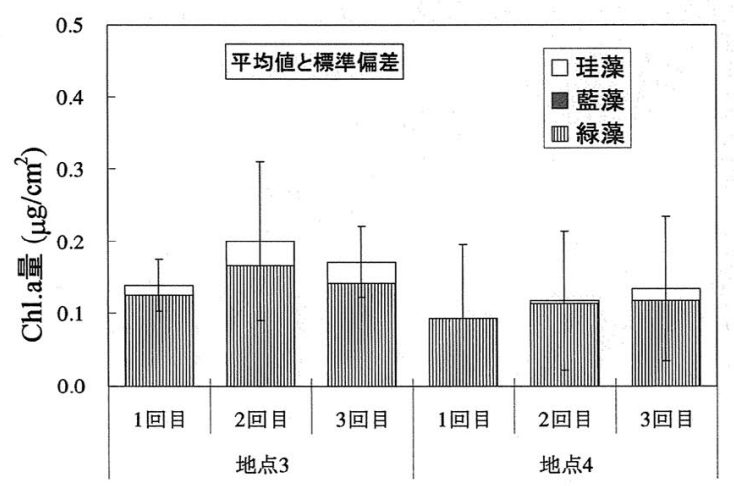

図-10 クロロフィル-aの時閒变化(2005年9月)

\section{（6）クロロフィル-aの季節変化}

2005年2月，3月，9月に阪南2区における造成干潟で実 施した測定結果のうち，干潟底面上で測定されたクロロ フィル-aの測定值を整理し，種組成の季節変化を調べた

(図-11)．その結果，2月および3月は，そのほとんど が珪藻であった，それに対し，9月はそのほとんどが緑 藻で構成されていた. このことから, 付着藻類の種組成 には，季節变化があり，本測定器はこの恋化を簡易に計 測することができた。

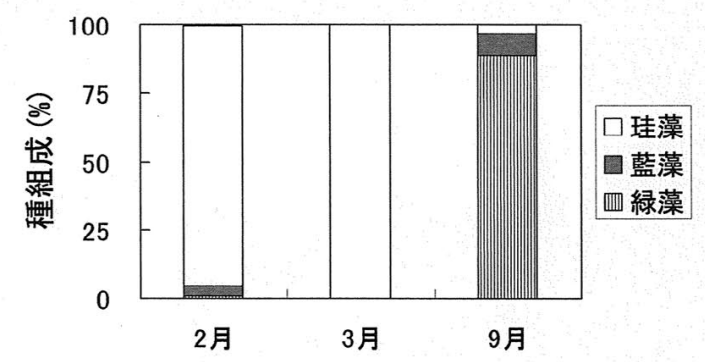

図-11 クロロフィル-aの種組成の季節変化

\section{（7）クロロフィルー $\mathrm{a}$ の部材別特性}

2005年9月に阪南2区における造成干潟で実施した干潟 底面上と岩・石・竹といった基質表面の現存量とその標 準偏差を図-12に示した。 母数は，干潟底面が $\mathrm{N}=96$ ，基 質表面が $\mathrm{N}=49$ であった。 どちらも基質表面の現存量が 干潟底面よりも高い傾向にあった。

本測定器は，表面のクロロフィル-aを対象にするもの で，干潟底面の地中に生息する付着藻類を直接測定する ことはできない。このため，干潟底面の付着藻類は実際 には深さ方向で積分しなければ，基質表面のクロロフィ ル-aと同レベルの比較はできない. 図-6に示したクロロ フィル-aの鉛直分布等をもとに，值を補正する必要があ る.

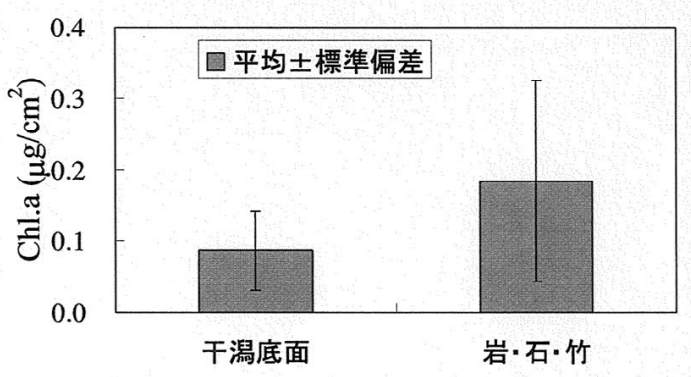

図-12 干潟表面と基質（岩・石・竹）の クロロフィル-a

\section{4. おわりに}

以上の携帯式蛍光光度計を用いた付着藻類のクロロ フィル-aの観測結果をまとめると，次のようになる.

分析值との比較 : 携帯式蛍光光度計によるクロロフィ ル-aの測定值と鉛直方向に $3 \sim 4 \mathrm{~mm}$ で採取した底質試料 のDMF抽出によるクロロフィル-aの分析値を比較すると, 比較的高い一次相関を示した. Bentho-Flourによる非破 壊測定法は，砂質干潟の底面上の，クロロフィル-a測定 に有効である.また，本測定器による鉛直方向の数mm 単位の精度での観測の可能性を示した.この結果から, 本調查で使用した携帯式蛍光光度計は，干潟のクロロ フィル-aの測定に有効と考える. 
留意事項として，測定値と分析值の一次式の勾配は， 干潟毎にわずかに異なる可能性があげられる。千潟相互 の定量的な比較を行うためには，干潟毎に測定值と分析 值を比較して，一次式を求める必要があり，今後の課題 である。

クロロフィル-a の平面的分布特性 : Bentho-Fluorは短 時間に多くの測定データを取得することができるため， 平面的なクロロフィル-aの測定は，可能となる．留意事 項として, 干潟の付着藻類の平面分布は，ばらつきが大 きいため，1回の測定では，地点を代表させる值とは言 い難く，できれば5回，最低でも3点の測定を行い，その 平均值をもって地点を代表する值とする必要がある.

クロロフィル-aの底質での分布特性：底質を $3 \sim 4 \mathrm{~mm}$ もしくは $1 \mathrm{~cm}$ 単位でスライスして干潟底面のクロロフィ ル-aを計測した, 東京湾と大阪湾の干潟での観測結果は, クロロフィル-aは表面で最も多く, 深くなるにつれて減 少し，深さ $2 \mathrm{~cm}$ 以上になるとほぼ測定されなかった。こ のように, Bentho-Fluorを用いることで梁さ方向に数mm 単位間隔での測定も可能となる。 また，その結果から， 現存量は，表層で高く，深くなるにつれて減少する分布 をしている様子を示していたことから，表面の測定のみ で面的なクロロフィル-aが把握できることが示唆された。 クロロフィル-aの分布と地盤高との関係 : 測線に沿つ たクロロフィル $-\mathrm{a} の$ 測定結果から，平均潮位 (D.L. $+95 \mathrm{~cm})$ よりも低い地盤高で比較的高く測定される 傾向があり，傾斜面よりも海底勾配のほとんどない平坦 地で高い傾向がみられた。このように, Bentho-Fluorを 用いることで，測線に沿ったクロロフィル-aの分布を容 易に測定することが可能になる．留意事項として，底質 付着藻類の分布は, 地盤高や地形 (海底勾配) に関係し ていることを念頭に入れて測定する必要がある.

クロロフィル-aの日変化 : 今回の観測では, 測定回数 が2または3回であったため, クロロフィル-aの明瞭な日 変化が得られなかった. よって, 留意事項は, 日変化を 把握するためには，測定時間間隔を短くとり，同時刻の 測定点数を多くとるなどの対処が必要で，今後の課題で ある. また，日変化の把握を対象としない場合も，測定 にあたっては，測定時刻を明記することが重要で，正確 を期する場合には, 数地点で日変化調查を行い調查時刻 による補正を行うなど，日変化への対処が今後の課題に あげられる。

クロロフィル-aの季節変化 : 阪南2区における造成干 潟で行った2月，3月，9月の測定結果から，2月と3月は珪 藻類が主であったが，9月は緑藻類が主であった。この
ように，Bentho-Fluorを用いることで，付着藻類のクロ ロフィル-aだけでなく，付着藻類の種組成の季節変化も 把握できる.

クロロフィル-aの部材別特性 : 干潟底面のクロロフィ ル-aと岩・石・竹といった基質表面のクロロフィル-aを 比較すると，基質表面の方が高い傾向にあった．本測定 器は表面を測定の対象とするため，干潟底面の地中に生 息するクロロフィル-aは含まれていない点に留意しなけ ればならない，このため，両者を同等に比較するために は，深さ方向に積分を行うなどの処理が必要と考えられ， 今後の課題である.

以上より，短時間で広域かつ詳細な計測が可能な携帯 式蛍光光度計を用いた付着藻類の現存量測定手法は，造 成干潟等の機能を評価する際のモニタリング調査手法と して有効であり, 従来の調查手法に加えて本手法を適用 することで，より多くの知見が得られることが期待され る.

\section{5. 謝辞}

本研究の一部は, 都市臨海部に干潟を取り戻すプロ ジェクト（国土技術政策総合研究所）の阪南2区干潟創 造実験として実施された. 阪南2区造成干潟への立ち入 り・調查実施に関しては，大阪府港湾局から許可をいた だいた，関係各位にお礼申し上げます。

\section{参考文献}

1）国土交通省港湾局監修/海の自然再生ワーキンググルー プ : 海の自然再生ハンドブック (第 2 巻干潟編)， 2003.

2）古川恵太・藤野智亮 - 三好英一・桑江朝比呂 - 野村宗 弘・萩本幸将・細川恭史 : 干潟の地形変化に関する現地観 測一盤洲干潟と西浦造成干潟一, 港湾技研資料, No.965, 2000.

3）古川恵太・岡田知也・東島義郎・橋本浩一 : 阪南2区にお ける造成干潟実験一都市臨海部に干潟を取り戻すプロジェ クトー, 海洋開発論文集, Vol.21, pp.659-664, 2005.

4) M.Beutler, K.H.Wiltshire, B.Meyer, C.Moldaenke, C.Luring, M.Meyerhoher, U.P.Hansen and H.Dau : A fluorometric method for the differentiation of algal populations in vivo and in situ, Photosynthesis Research, 72, pp.39-53, 2002.

5）門谷茂：特集 瀬戸内海の現状と干潟域における物質循環, 海洋と生物 129, Vol.22, No.4, pp.323-331, 2000. 